\title{
Protection from yellow head virus (YHV) infection in Penaeus vannamei pre-infected with Taura syndrome virus (TSV)
}

\author{
Luis Fernando Aranguren ${ }^{1,2, *}$, Kathy F. J. Tang ${ }^{1}$, Donald V. Lightner ${ }^{1}$ \\ ${ }^{1}$ Aquaculture Pathology Laboratory, Department of Veterinary Science and Microbiology, University of Arizona, \\ 1117 E. Lowell St., Tucson, Arizona 85719, USA \\ ${ }^{2}$ Corporación Centro de Investigación de la Acuacultura de Colombia (CENIACUA), Cra 9B-113-60, Bogotá, Colombia
}

\begin{abstract}
Pacific white shrimp Penaeus vannamei that were pre-exposed to Taura syndrome virus (TSV) and then challenged with yellow head virus (YHV) acquired partial protection from yellow head disease (YHD). Experimental infections were carried out using specific-pathogenfree (SPF) shrimp which were first exposed per os to TSV; at 27, 37 and $47 \mathrm{~d}$ post infection they were then challenged by injection with $1 \times 10^{4}$ copies of YHV per shrimp (designated the TSVYHV group). Shrimp not infected with TSV were injected with YHV as a positive control. Survival analyses comparing the TSV-YHV and YHV (positive control) groups were conducted, and significant survival rates were found for all the time groups $(p<0.001)$. A higher final survival was found in the TSV-YHV group (mean $55 \%)$ than in the positive control $(0 \%)(p<0.05)$. Duplex reverse transcription quantitative PCR was used to quantify both TSV and YHV. Lower YHV copy numbers were found in the TSV-YHV group than in the positive control in pleopods $\left(3.52 \times 10^{9} \mathrm{Vs}\right.$. $1.88 \times 10^{10}$ copies $\mu g$ RNA $\left.^{-1}\right)(p<0.001)$ and lymphoid organ $(\mathrm{LO})$ samples $\left(3.52 \times 10^{9}\right.$ vs. $1.88 \times$ $10^{10}$ copies $\left.\mu \mathrm{g} \mathrm{RNA}^{-1}\right)(\mathrm{p}<0.01)$. In situ hybridization assays were conducted, and differences in the distribution of the 2 viruses in the target tissues were found. The foci of LO were infected with TSV but were not infected with YHV. This study suggests that a viral interference effect exists between TSV and YHV, which could, in part, explain the absence of YHD in the Americas, where $P$. vannamei are often raised in farms where TSV is present.
\end{abstract}

KEY WORDS: Taura syndrome virus - TSV - Yellow head virus · YHV - Penaeus vannamei · Duplex RT-qPCR $\cdot$ In situ hybridization

\section{INTRODUCTION}

Viral diseases are the most important cause of shrimp losses in commercial shrimp farming. Taura syndrome virus (TSV) and Gill-associated virus strain yellow head virus (YHV) (King et al. 2011) are considered 2 of the most pathogenic viruses present in shrimp farming in the western and eastern hemisphere, respectively. TSV (the causative agent of Taura syndrome disease, TSD) was first reported in Penaeus vannamei juveniles in Ecuador (Lightner et al. 1995). After it emerged in Ecuador, TSD spread through most of the shrimp culturing regions in the western hemisphere, and it later appeared in Southeast Asian countries in $P$. vannamei cultures (Tu et al. 1999, Yu \& Song 2000). At about the same time that TSV was emerging in Ecuador, YHV (the causative agent of yellow head disease, YHD) was reported in Asian shrimp-farming countries. YHD was first reported in Thailand in 1990 in Penaeus monodon juveniles (Limsuwan 1991, Boonyaratpalin et al. 1993); later on, YHD was reported in other countries, including India, Indonesia, Malaysia, the Philippines, Sri Lanka, Vietnam and Taiwan (Mohan 
et al. 1998, Wang \& Chang 2000, Walker et al. 2001). YHV has been detected in the western hemisphere using reverse transcription (RT)-PCR. Nunan et al. (1998) and Durand et al. (2000) found YHV in imported frozen commodity shrimp from Asia. In 1999, some samples from an Ecuadorian farm showed a positive RT-PCR result for YHV (CENAIM 2000). Recently, YHV was reported from the Pacific coast of Mexico in shrimp from the Gulf of California and from several farms (de la Rosa-Velez et al. 2006, Sánchez-Barajas et al. 2009).

TSV is a non-enveloped, icosahedral virus that contains a single-strand, positive-sense RNA genome of $10.2 \mathrm{~kb}$ and belongs to the family Dicistroviridae (Bonami et al. 1997, Mayo 2005). TSV contains 2 open reading frames (ORFs). ORF1 encodes the non-structural proteins: a helicase, a protease and an RNA-dependent RNA polymerase (RdRp). ORF2 encodes 3 capsid proteins: CP1 (40 kDa), CP2 (55 kDa) and CP3 (24 kDa) (Mari et al. 2002). YHV is an enveloped, positive-sense ssRNA genome virus of $26.6 \mathrm{~kb}$ that belongs to the genus Okavirus within the family Roniviridae (Cowley \& Walker 2002, Walker et al. 2005) and contains 4 ORFs. ORF 1 encodes the protease, helicase and RdRp. ORF 2 encodes the nucleocapsid. ORF 3 codes for glycoproteins (gp116 and gp64), and the encoded product of ORF 4 is not known (Sittidilokratna et al. 2008).

One of the common characteristics of YHV and TSV is that they share many of the same target tissues. During the acute phase of infection, TSV and YHV infect the cuticular epithelium (CE) of the foregut and hindgut, stomach, gills and pleopods. Unlike TSV, during the acute phase, YHV also targets other organs, such as the lymphoid organ (LO), connective tissue and hemocytes (Boonyaratpalin et al. 1993, Lightner 1996). During the chronic phase of infection, TSV and YHV produce LO spheroids in infected shrimp (Hasson et al. 1999a, Anantasomboon et al. 2008).

Because TSV and YHV viruses share similar target tissues and because TSV was already present in the Americas at about the same time that YHV was becoming pandemic in Asia, it is possible that TSV prevented shrimp from becoming infected with YHV during one of the several times at which frozen material from Asia infected with YHV and white spot syndrome virus (WSSV) (Nunan et al. 1998) only resulted in the introduction of white spot disease (WSD) to shrimp farms in the Americas. Thus, the objective of this work was to evaluate the viral interactions in shrimp pre-infected with TSV and then challenged with YHV under experimental conditions.

\section{MATERIALS AND METHODS}

\section{Shrimp and viruses}

The TSV isolate used in this study was obtained from Hawaii (designated as HW) in 1994, and the YHV isolate was obtained in 1993 from farm-raised Penaeus monodon in Thailand. Both viruses were stored at $-70^{\circ} \mathrm{C}$ at the University of Arizona and, just prior to the challenge, were amplified by transfer in a specific-pathogen-free (SPF) line of P. vannamei, the 'Kona line' (Pruder et al. 1995). The same line was used in this study. All of the experimental infections were carried out at the Aquaculture Pathology Laboratory (APL) in the University of Arizona.

\section{YHV inoculum}

YHV-infected tissue was prepared using frozen samples. Only frozen YHV-infected shrimp Penaeus vannamei heads, excluding the hepatopancreas, were homogenized in a buffer $(0.02 \mathrm{M}$ Tris- $\mathrm{HCl}$, $\mathrm{pH} 7.4,0.4 \mathrm{M} \mathrm{NaCl}$ buffer; $1 \mathrm{~g} 10 \mathrm{ml}^{-1}$ ) using a tissue blender and clarified at $3500 \times g$ for $20 \mathrm{~min}$ and $5000 \times g$ for $20 \mathrm{~min}$ at $4^{\circ} \mathrm{C}$. Tissue homogenates were diluted (1:20) in $2 \%$ saline, aliquoted and frozen.

\section{YHV lethal dosage}

A titration with YHV was carried out to determine the highest dose at which mortality between 50 and $100 \%$ occurred. Eight 60 l aquaria with 10 SPF juvenile shrimp were used in this study. Four different YHV inocula were tested in duplicate $\left(1 \times 10^{2}\right.$ through $1 \times 10^{5}$ viral copies per shrimp, at a 10 -fold serial dilution) using a single injection (100 $\mu \mathrm{l})$. In Fig. 1, the final survival is shown $14 \mathrm{~d}$ after infection.

\section{Pre-infection with TSV}

A total of 200 SPF Penaeus vannamei were stocked in a 10001 round tank and challenged with TSV per os; they were fed minced infected tissue corresponding to $10 \%$ of their body weight. 


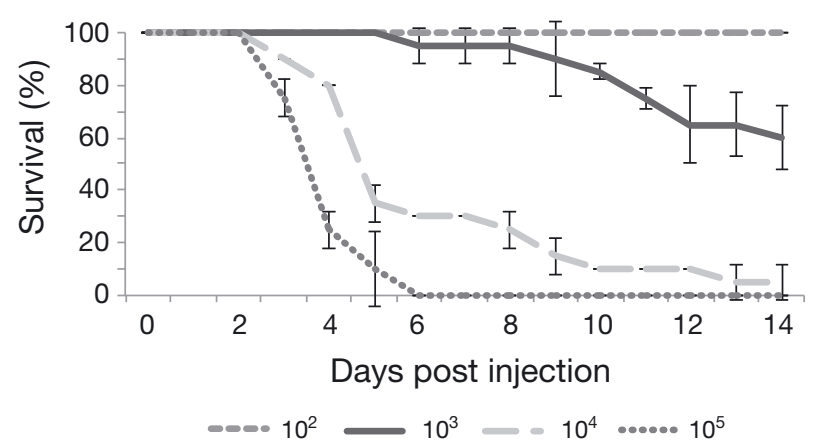

Fig. 1. Penaeus vannamei. Survival (mean $\pm 1 \mathrm{SE}$ ) after challenge with yellow head virus (YHV) by intramuscular injection at 4 different concentrations $\left(1 \times 10^{2}\right.$ to $1 \times 10^{5}$ viral copies per shrimp). Each YHV concentration was done in duplicate

\section{Injection of TSV-pre-infected shrimp with YHV}

For the experimental infection of shrimp preinfected with TSV and then challenged with YHV (the TSV-YHV group), 3 groups in duplicate were tested 27, 37 and $47 \mathrm{~d}$ after infection with TSV, all with their respective negative control (shrimp injected with $2 \%$ saline) and positive control (shrimp infected only with YHV; the YHV group). In each $90 \mathrm{l}$ tank, 10 shrimp (mean weight: 5 g) were placed. The salinity and temperature were adjusted at $25 \mathrm{ppt}$ and $26 \pm 1^{\circ} \mathrm{C}$, respectively. Shrimp were infected with a YHV inoculum by a single intramuscular injection of $1.0 \times 10^{4}$ copies of YHV per shrimp in a $100 \mu \mathrm{l}$ volume. Mortality was recorded twice per day from the start of the experiment. The cephalothoraxes of moribund shrimp were fixed in Davidson's AFA fixative (Bell \& Lightner 1988) for hematoxylin and eosin histological analysis. Moribund and dead animals were immediately frozen and stored at $-70^{\circ} \mathrm{C}$.

\section{RNA extraction}

Pleopods from the first abdominal segment were removed from each shrimp to determine the TSV and YHV viral genetic load. Some samples of the LO and adjacent areas were taken to determine the viral genetic load as well. Total RNA was extracted using the RNeasy extraction kit (Qiagen) according to the manufacturer's recommendations. The concentration of the extracted RNA was determined by measuring the optical density at $260 \mathrm{~nm}$.

\section{Duplex TSV and YHV RT-qPCR}

The RT quantitative PCR (qPCR) primers/TaqMan probe for TSV RT-qPCR (TSV1004F: 5'-TTG GGC ACC AAA CGA CAT T-3'; TSV1075R: 5'-GGG AGC TTA AAC TGG ACA CAC TGT-3'; and TSV-P1: FAM-5'-CAG CAC TGA CGC ACA ATA TTC GAG CAT C-BHQ1) have been described previously (Tang et al. 2004). The primers and TaqMan probe for YHV (YHV141F: 5'-CGT CCC GGC AAT TGT GAT C-3'; YHV206R: 5'-CCA GTG ACG TTC GAT GCA ATA-3'; and YHV-P1: MAX NHS ester-5'-CCA TCA AAG CTC TCA ACG CCG TCA-BHQ1) were designed from the conserved region, ORF1, of the viral genome. The duplex RT-qPCR was carried out in a $25 \mu \mathrm{l}$ reaction mixture containing $12.5 \mu \mathrm{l}$ of TaqMan 1-step RT-PCR master mixture (Applied Biosystems), $20 \mathrm{ng}$ of extracted RNA, each primer at a concentration of $0.3 \mu \mathrm{M}$ and the TaqMan probe at a concentration of $0.1 \mu \mathrm{M}$. The RT-qPCR was performed on a Mastercycler ep realplex (Eppendorf) under the following conditions: $48^{\circ} \mathrm{C}$ for $30 \mathrm{~min}$ for reverse transcription and $10 \mathrm{~min}$ at $95^{\circ} \mathrm{C}$, followed by 40 cycles of $95^{\circ} \mathrm{C}$ for $15 \mathrm{~s}$ and $60^{\circ} \mathrm{C}$ for $1 \mathrm{~min}$. Amplification data were collected and analyzed with the Realplex 2.0 software (Eppendorf). The detection and quantification of TSV and YHV were from channels detecting FAM and JOE dyes, respectively.

\section{In situ hybridization (ISH)}

For ISH, histological sections of 4 to $5 \mu \mathrm{m}$ thickness were prepared from Davidson's fixed and paraffinembedded shrimp tissues. Digoxigenin-labeled probes and colorimetric detection of the anti-DIG Fab fragment (alkaline phosphatase conjugate) with nitroblue tetrazolium and X-phosphate was used. For YHV and TSV ISH assays, the protocols developed by Tang \& Lightner (1999) and Mari et al. (1998) were used, respectively.

\section{Statistical analysis}

Statistical analyses were conducted in STATA IC10. The survival data and the cumulative survival probabilities were determined using a Kaplan-Meier survival analysis. Bartlett tests were used to determine the equal variances. A 1-way ANOVA $(\alpha=$ $0.05)$ was used to determine if statistical differences existed in the viral genetic load among groups and in the final survivals. 


\section{RESULTS}

\section{Generation of chronically TSV-infected shrimp}

Penaeus vannamei were infected with TSV using an established laboratory challenge method. Two weeks after the exposure to TSV, $28 \%$ of the infected shrimp survived and went through a typical transition phase characterized by multifocal melanized areas in the cuticle of the cephalothorax and abdomen. After molting, no further clinical signs were observed as the TSV-challenged shrimp became chronically infected.

\section{YHV titration}

To determine the YHV titer for the challenge study, 4 inocula were tested. The injection of $1 \times 10^{2}, 1 \times 10^{3}$, $1 \times 10^{4}$, and $1 \times 10^{5}$ copies of YHV per shrimp resulted in 0, 40, 95 and $100 \%$ mortality, respectively (Fig. 1). Thus, an inoculum containing $1 \times 10^{4}$ copies of YHV per shrimp was used in the challenge tests to evaluate if the chronically TSV-infected shrimp were protected from infection by YHV.

\section{YHV challenge test in the TSV-infected shrimp}

The challenge test showed differences in the final survival and in the survival curves between the groups exposed previously to TSV and then challenged with YHV (the TSV-YHV group) and the positive control infected only with YHV (Fig. 2). The negative control group had a final survival of $100 \%$. The positive control showed a final survival of $0 \%$ in all 3 groups. Significant differences in survival were found among the 3 groups that had been preexposed to TSV for 27, 37 and $47 \mathrm{~d}$ prior to the challenge with YHV ( $p<0.05)$. A Kaplan-Meier analysis of the survival values showed significant differences in the survival curves $(p<0.001)$.

\section{Quantification of viral genetic load using RT-qPCR}

The YHV quantities in the TSV-YHV (chronically TSV-infected and injected with YHV) and YHV (positive control) groups were determined and compared using a duplex RT-qPCR for TSV and YHV. The YHV viral genetic load in pleopod and LO samples showed similar results after 27, 37 and $47 \mathrm{~d}$ post TSV infection ( $p>0.05)$. A 5-fold higher YHV viral genetic load was
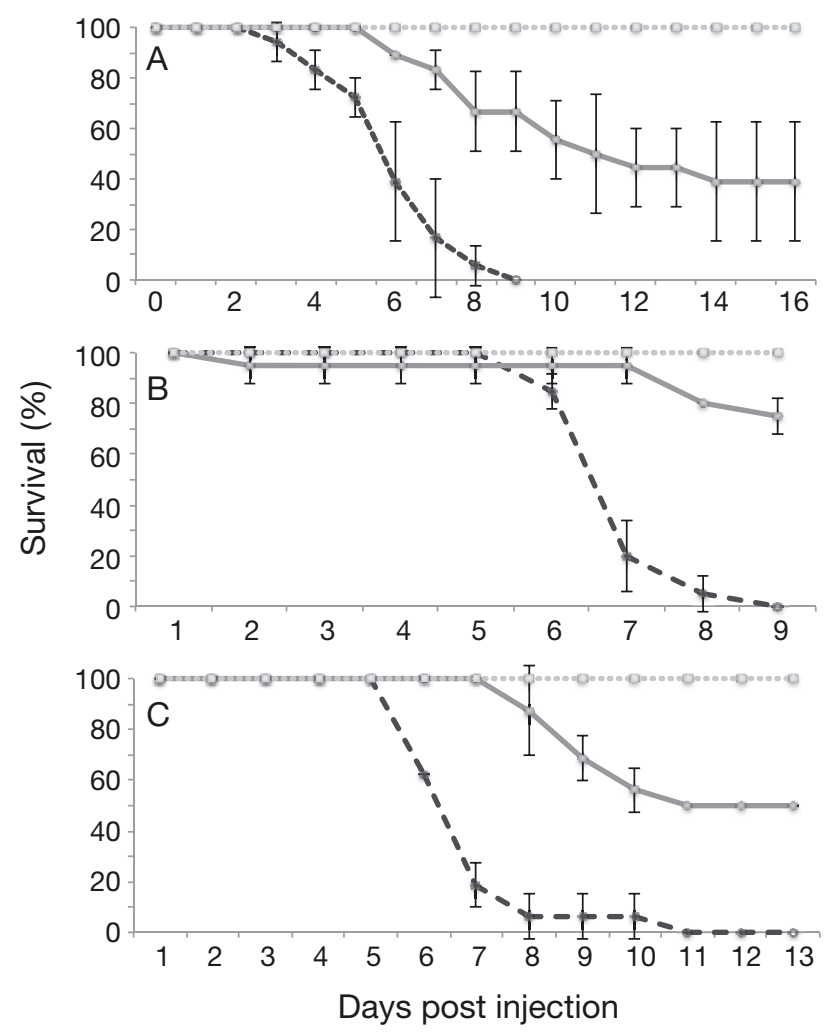

$\simeq$ TSV-YHV $\ldots$ YHV ..... Negative control

Fig. 2. Cumulative survival of specific-pathogen-free Penaeus vannamei pre-exposed to Taura syndrome virus (TSV) that were challenged with YHV $\left(1 \times 10^{4}\right.$ copies per shrimp) (TSV-YHV group, solid line); positive control (shrimp infected only with YHV, dashed line) and negative control (dotted line). Animals were infected with TSV then with YHV at (A) 27, (B) 37 (C) 47 d after infection with TSV. Data shown are the average of 2 replicates. Error bars represent the $95 \%$ confidence interval of the data set

found in pleopods in the positive control group than in the TSV-YHV group $\left(1.88 \times 10^{10}\right.$ copies $\mu g$ RNA $^{-1}$ in the positive control group vs. $3.52 \times 10^{9}$ copies $\mu \mathrm{g}$ RNA $^{-1}$ in the TSV-YHV group) ( $<<0.001$ ) (Fig. 3). The YHV copy number in the LO of the TSV-YHV was 5.8-fold lower than in the positive control $(4.15 \times$ $10^{9}$ copies $\mu \mathrm{g} \mathrm{RNA}^{-1}$ in the TSV-YHV group vs. $2.41 \times$ $10^{10}$ copies $\mu \mathrm{gNA}^{-1}$ in the positive control), values that were significantly different ( $p=0.01$ ) (Fig. 3).

The TSV viral genetic load in pleopod samples showed similar results after 27, 37 and $47 \mathrm{~d}$ post TSV infection ( $\mathrm{p}>0.05)$, with a mean of $9.25 \times 10^{7}$ copies $\mu \mathrm{g} \mathrm{RNA}^{-1}$. The mean TSV copy number in LO was $5.78 \times 10^{8}$ copies $\mu \mathrm{g} \mathrm{RNA}^{-1}$, significantly higher that that in pleopods ( $\mathrm{p}<0.005)$. This TSV distribution has been reported previously (Tang et al. 2004), and it is related to the typical TSV chronic phase when most of 


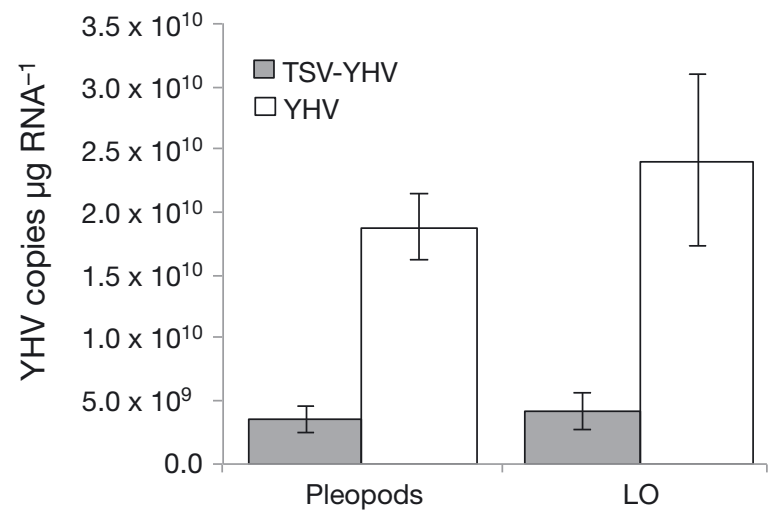

Fig. 3. Comparison of YHV copy number in pleopods and lymphoid organ (LO) of dead shrimp exposed only to YHV (YHV; positive control) versus shrimp pre-exposed to TSV and then challenged with YHV (the groups tested 27, 37 and $47 \mathrm{~d}$ after pre-infection were combined and the means are shown). Error bars represent the $95 \%$ confidence interval of the data set the TSV viral particles are harbored in this organ and circulating in the hemolymph (Poulos et al. 2008). When comparing the TSV and YHV viral genetic loads of dead or surviving shrimp from the same group, a higher copy number of YHV was found in the dead shrimp $\left(3.52 \times 10^{9}\right.$ copies $\mu g \mathrm{RNA}^{-1}$ in the dead shrimp versus $8.91 \times 10^{8}$ copies $\mu \mathrm{RNA}^{-1}$ in the surviving shrimp) $(p<0.05)$, suggesting that the mortalities observed were caused by YHV and not by TSV.

The results from the ISH confirmed that the shrimp were infected with the 2 viruses. However, as expected, the distribution of the viruses was different. TSV presence was restricted to the LO, whereas YHV was found in the $\mathrm{CE}$, connective tissue and LO (Fig. 4). Interestingly, the distribution of TSV in the LO seemed to be mainly in the LO tubules, while YHV seemed to be present in areas where TSV was not present and in adjacent areas of the tubules,

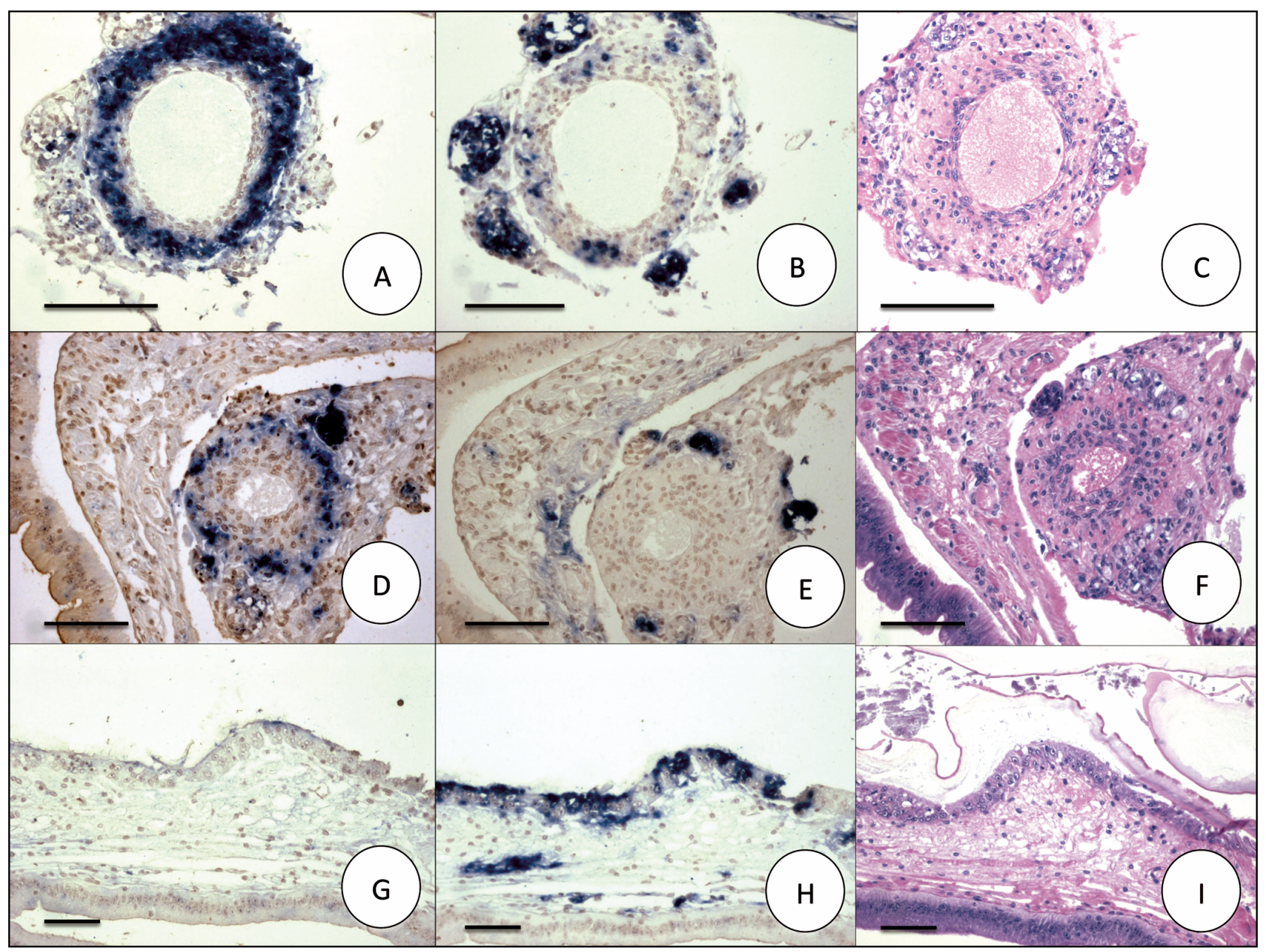

Fig 4. Histology of specific-pathogen-free Penaeus vannamei pre-infected with TSV and then challenged with YHV. (A,D,G) Results of TSV in situ hybridization (ISH). (B,E,H) Results of YHV ISH at 37 and $47 \mathrm{~d}$ after infection. (C,F,I) Hemotoxylin and eosin stained sections. (A-F) LO sections; (G-I) stomach cuticular epithelium sections. Scale bars $=50 \mu \mathrm{m}$ 
including LO spheroids (LOS). The typical severe necrosis caused by acute YHV was not observed in the LO of shrimp pre-infected with TSV (Fig. 4). TSV was not present in CE, and only YHV was present (Fig. $4 \mathrm{G}, \mathrm{H}, \mathrm{I})$, a finding that is consistent with the TSV chronic phase and YHV acute phase.

\section{DISCUSSION}

In the present study, a clear effect of viral interference was observed when shrimp were pre-exposed to TSV and then infected with YHV. This interaction of TSV on YHV infection reduced the mortality, and hence, an increase in survival was observed. The higher final survival in the TSV-YHV group is explained in part by the lower YHV viral genetic load in the pleopods and LO in this group. In addition, the restriction of YHV distribution to areas of the LO where TSV was not present may have protected this organ from the severe necrosis that was observed only in the positive control group.

Previous studies have shown a correlation between viral copy number and higher mortalities. Srisuvan et al. (2006) found in TSV studies that the higher mortalities of a Belize TSV strain were associated with a higher viral genetic load present in the TSV-infected shrimp during a TSV challenge test. In our study, the YHV viral genetic load in the LO and pleopods of the positive control was significantly higher than in the TSV-YHV group; this finding could explain, in part, the higher mortality in the positive control group.

It is known that TSV and YHV have some common target tissues, such as the $\mathrm{CE}$, in acute phase infections. TSV in the acute phase does not infect the LO. A strong positive reaction is observable using ISH in the LO only during the transition and the chronic phases (Hasson et al. 1999b, Poulos et al. 2008). At that time, a higher viral genetic load is present in the LO than in pleopods (Tang et al. 2004). In contrast to TSV, the target tissues for YHV during the acute phase are the LO, hematopoietic tissue, connective tissue and hemocytes (Lightner 1996). The YHV copy number was lower in the pleopods and LO of the TSV-YHV group, indicating that YHV was not able to effectively infect tissues pre-infected with TSV, such as LO and CE. Similar results were observed during histological analyses. In the TSV-YHV group, YHV was present; however, the typical severe necrosis of the LO was not observed, although it was observed in the positive control. The ISH results showed that infection by the 2 viruses occurred in the $\mathrm{LO}$, which was also confirmed by the RT-qPCR analysis. The same tissue can harbor the 2 viruses; however, the regions of the LO that were infected first by TSV were not infected or were only lightly infected with YHV. The interaction between TSV and YHV is probably due to TSV interfering with the YHV infection. This hypothesis is supported by the lower copy number of YHV in the TSV-YHV group. The lower copy number for YHV might prevent the shrimp from severe acute necrosis of the LO, which, in turn, might reduce the mortality.

Viral interaction has been reported for other shrimp viruses, such as WSSV and infectious hypodermal and hematopoietic necrosis virus (IHHNV). These 2 viruses also share the same or similar target tissues (CE, connective tissue and hemocytes). Shrimp pre-infected with IHHNV and then challenged with WSSV are partially protected from WSD for several possible reasons, possibly because IHHNV may block the entry of WSSV, possibly by down-regulation of the viral receptor(s) or perhaps by competition for common receptors (Tang et al. 2003, Bonnichon et al. 2006). In insects, similar phenomena have been reported in vitro for some cell lines. C6/36 Aedes albopictus cell lines infected with Aedes albopictus densovirus are protected from dengue virus (Burivong et al. 2004).

In some recent studies, it has been proposed that the cell receptor for the TSV capsid protein (CP2) is the laminin receptor (Lamr) (Senapin \& Phongdara 2006), and recently, Lamr was found to also be the cell receptor for the YHV gp116 envelope protein (Busayarat et al. 2011). Thus, Lamr is the cell receptor for these 2 viruses. In our study, in shrimp preinfected with TSV, it is likely that TSV occupies the cell receptors first and thus blocks the YHV infection in those areas. The competition between CP2 and gp116 for the cell receptor would limit the infection of the 2 viruses in the same region. In rainbow trout, Brudeseth et al. (2002) observed that the same cell receptor is used for 2 RNA viruses: viral hemorrhagic septicemia virus (VHSV) and infectious hematopoietic necrosis virus (IHNV); VHSV restricts the distribution of IHNV in some tissues by competition for cell receptors. The difference in the viral genetic load found in our study in the TSV-YHV group versus the positive control, supports the hypothesis that the first pathogen excludes or reduces infection by the second pathogen.

There are other possible explanations for the interference effect between TSV and YHV. The resistance to YHV could be due to a mechanism involved in 
resistance against TSV that indirectly results in resistance to YHV. However, there is no evidence that this type of phenomena occurs in shrimp. The only study in which interaction between shrimp RNA viruses has been reported, was conducted by White-Noble et al. (2010). Shrimp highly resistant to TSV are more susceptible to IMNV than the SPF control (WhiteNoble et al. 2010), which suggests that genes involved in the resistance of TSV are different from those involved in IMNV resistance. Longyant et al. (2006) and Chaivisuthangkura et al. (2008) reported that resistance to YHV was found in shrimp that are able to reduce expression of gp116. It is possible that survivors of a TSV infection have the ability to suppress the expression of attachment proteins, such as CP2 in the case of TSV and gp116 in the case of YHV.

The increased resistance of TSV survivors to the YHV challenge might also be attributed to an inherent resistance to viral infection rather than to interference by the pre-existing TSV infection of the selected shrimp. However, if this had occurred in our study, at least some of the shrimp from the YHV group would have survived after the infection with YHV, but in all of the challenge tests, the final survival was always $0 \%$, which suggests that this resistance is unlikely.

YHV has been suspected to be present in some locations in the western hemisphere where shrimp are cultured, and sporadic positive results from RTPCR suggest the presence of this etiological agent. Nunan et al. (1998) and Durand et al. (2000) found YHV in samples from imported commodity shrimp from Asia. In 2006, YHV was reported on the Pacific coast of Mexico in wild shrimp (Castro-Longoria et al. 2008) and in farm-raised shrimp (de la Rosa-Velez et al. 2006, Sánchez-Barajas et al. 2009), and it was proven that this strain was infectious (CedanoThomas et al. 2010). Thus, one of the possible explanations for the absence of YHD in Penaeus vannamei cultures in the Americas could be the widespread presence of TSV before YHV arrived with WSSV. TSV is currently endemic in many Latin-American shrimp farming areas (Lightner 1996, 2011); thus, shrimp pre-exposure to TSV might block the entry of YHV by competing for the cell receptor. Although YHV can still infect other tissues that TSV cannot, it is likely that the critical tissues, such as the LO and $\mathrm{CE}$, are essential for YHV pathogenesis. Thus, by blocking the entry into those tissues, prevention of viral infection of other target tissues could be achieved. Additional work is needed to elucidate the whole blocking process at the molecular level.
Acknowledgements. This work was supported by the Gulf Coast Research Laboratory Consortium Marine Shrimp Farming Program, USDA Grant No. USMSFD 2010-3880521115, NOAA, Saltonstall-Kennedy Grant No. NA09NMF4270102 and a special grant from the National Fisheries Institute. We thank B. White-Noble for providing technical assistance and R. Redman for histological services.

\section{LITERATURE CITED}

Anantasomboon G, Poonkhum R, Sittidilokratna N, Flegel TW, Withyachumnarnkul B (2008) Low viral loads and lymphoid organ spheroids are associated with yellow head virus (YHV) tolerance in whiteleg shrimp Penaeus vannamei. Dev Comp Immunol 32:613-626

Bell TA, Lightner DV (1988) A handbook of normal penaeid shrimp histology. World Aquaculture Society, Baton Rouge, LA

> Bonami JR, Hasson KW, Mari J, Poulos BT, Lightner DV (1997) Taura syndrome of marine penaeid shrimp: characterization of the viral agent. J Gen Virol 78:313-319

- Bonnichon V, Lightner DV, Bonami JR (2006) Viral interference between infectious hypodermal and hematopoietic necrosis virus and white spot syndrome virus in Litopenaeus vannamei. Dis Aquat Org 72:179-184

Boonyaratpalin S, Supamattaya K, Kasornchandra J, Direkbusaracom S, Aekpanithanpong U, Chantanachookin C (1993) Non-occluded baculo-like virus, the causative agent of yellow head disease in the black tiger shrimp (Penaeus monodon). Fish Pathol 28:103-109

Brudeseth BE, Castric J, Evensen Ø (2002) Studies on pathogenesis following single and double infection with viral hemorrhagic septicemia virus and infectious hematopoietic necrosis virus in rainbow trout (Oncorhynchus mykiss). Vet Pathol 39:180-189

Burivong P, Pattanakitsakul SN, Thongrungkiat S, Malasit $\mathrm{P}$, Flegel TW (2004) Markedly reduced severity of Dengue virus infection in mosquito cell cultures persistently infected with Aedes albopictus densovirus (AalDNV). Virology 329:261-269

- Busayarat N, Senapin S, Tonganunt M, Phiwsaiya K and others (2011) Shrimp laminin receptor binds with capsid proteins of two additional shrimp RNA viruses YHV and IMNV. Fish Shellfish Immunol 31:66-72

Castro-Longoria R, Quintero Arredondo N, Grijalva Chon J, Ramos Paredes J (2008) Detection of the yellow head virus (YHV) in wild blue shrimp, Penaeus stylirostris, from the Gulf of California and its experimental transmission to the Pacific white shrimp, Penaeus vannamei. J Fish Dis 31:953-956

Cedano Thomas Y, de la Rosa Vélez J, Bonami JR, Vargas Albores F (2010) Gene expression kinetics of the yellow head virus in experimentally infected Litopenaeus vannamei. Aquacult Res 41:1432-1443

CENAIM (Centro Nacional de Acuicultura e Investigaciones Marinas) (2000) Boletin informativo, CENAIM informa. 30 de Abril 2000. Internal bulletin, CENAIM, Guayaquil

Chaivisuthangkura $\mathrm{P}$, Tejangkura T, Rukpratanporn S, Longyant S, Sithigorngul W, Sithigorngul P (2008) Preferential suppression of yellow head virus (YHV) envelope protein gp116 in shrimp that survive challenge with YHV. Dis Aquat Org 79:1-8

Cowley JA, Walker PJ (2002) The complete genome sequence of gill-associated virus of Penaeus monodon 
prawns indicates a gene organisation unique among nidoviruses. Arch Virol 147:1977-1987

de la Rosa Vélez J, Cedano Thomas Y, Cid Becerra J, Méndez Payán J, Vega Pérez C, Zambrano García J, Bonami J (2006) Presumptive detection of yellow head virus by reverse transcriptase polymerase chain reaction and dot blot hybridization in Litopenaeus vannamei and L. stylirostris cultured on the Northwest coast of Mexico. J Fish Dis 29:717-726

> Durand S, Tang K, Lightner D (2000) Frozen commodity shrimp: potential avenue for introduction of white spot syndrome virus and yellow head virus. J Aquat Anim Health 12:128-135

Hasson KW, Lightner DV, Mari J, Bonami JR and others (1999a) The geographic distribution of Taura syndrome virus (TSV) in the Americas: determination by histopathology and in situ hybridization using TSV-specific cDNA probes. Aquaculture 171:13-26

Hasson KW, Lightner DV, Mohney LL, Redman RM, White BM (1999b) Role of lymphoid organ spheroids in chronic Taura syndrome virus (TSV) infections in Penaeus vannamei. Dis Aquat Org 38:93-105

King AMQ, Lefkowitz E, Adams MJ, Carstens EB (2011) Virus taxonomy: 9th report of the International Committee on Taxonomy of Viruses, 1st edn. Elsevier, San Diego, CA

Lightner DV (1996) A handbook of shrimp pathology and diagnostic procedures for diseases of cultured penaeid shrimp. World Aquaculture Society, Baton Range, LA

Lightner DV (2011) Virus diseases of farmed shrimp in the Western Hemisphere (the Americas): a review. J Invertebr Pathol 106:110-130

Lightner D, Redman R, Hasson K, Pantoja C (1995) Taura syndrome in Penaeus vannamei (Crustacea: Decapoda): gross signs, histopathology and ultrastructure. Dis Aquat Org 21:53-59

Limsuwan C (1991) Handbook for cultivation of black tiger prawns. Tansetakit, Bangkok

Longyant S, Sattaman S, Chaivisuthangkura P, Rukpratanporn S, Sithigorngul W, Sithigorngul P (2006) Experimental infection of some penaeid shrimps and crabs by yellow head virus (YHV). Aquaculture 257:83-91

- Mari J, Bonami JR, Lightner DV (1998) Taura syndrome of penaeid shrimp: cloning of viral genome fragments and development of specific gene probes. Dis Aquat Org 33: 11-17

Mari J, Poulos BT, Lightner DV, Bonami JR (2002) Shrimp Taura syndrome virus: genomic characterization and similarity with members of the genus Cricket paralysislike viruses. J Gen Virol 83:915-926

- Mayo MA (2005) Changes to virus taxonomy 2004. Arch Virol 150:189-198

> Mohan CV, Shankar KM, Kulkarni S, Sudha PM (1998) Histopathology of cultured shrimp showing gross signs of yellow head syndrome and white spot syndrome during 1994 Indian epizootics. Dis Aquat Org 34:9-12

Nunan L, Poulos B, Lightner D (1998) The detection of white spot syndrome virus (WSSV) and yellow head virus (YHV) in imported commodity shrimp. Aquaculture 160: 19-30

> Poulos BT, Noble BW, Lightner DV (2008) Comparison of Taura syndrome virus (TSV) detection methods during chronic-phase infection in Penaeus vannamei. Dis Aquat Org 82:179-185

Pruder GD, Brown CL, Sweeney JN, Carr WH (1995) High health shrimp systems: seed supply - theory and practice. In: Browdy CL, Hopkins JS (eds) Swimming through troubled water. Proc Special Session on Shrimp Farming. Aquaculture 1995, San Diego. World Aquaculture Society, Baton Rouge, LA, p 40-52

> Sánchez-Barajas M, Liñán-Cabello MA, Mena-Herrera A (2009) Detection of yellow-head disease in intensive freshwater production systems of Litopenaeus vannamei. Aquacult Int 17:101-112

Senapin S, Phongdara A (2006) Binding of shrimp cellular proteins to Taura syndrome viral capsid proteins VP1, VP2 and VP3. Virus Res 122:69-77

Sittidilokratna N, Dangtip S, Cowley JA, Walker PJ (2008) RNA transcription analysis and completion of the genome sequence of yellow head nidovirus. Virus Res 136: $157-165$

Srisuvan T, Noble BL, Schofield PJ, Lightner DV (2006) Comparison of four Taura syndrome virus (TSV) isolates in oral challenge studies with Litopenaeus vannamei unselected or selected for resistance to TSV. Dis Aquat Org 71:1-10

Tang KF, Lightner DV (1999) A yellow head virus gene probe: nucleotide sequence and application for in situ hybridization. Dis Aquat Org 35:165-173

> Tang KF, Durand SV, White BL, Redman RM, Mohney LL, Lightner DV (2003) Induced resistance to white spot syndrome virus infection in Penaeus stylirostris through preinfection with infectious hypodermal and hematopoietic necrosis virus - a preliminary study. Aquaculture 216: $19-29$

Tang KFJ, Wang J, Lightner DV (2004) Quantitation of Taura syndrome virus by real-time RT-PCR with a TaqMan assay. J Virol Methods 115:109-114

Tu C, Huang HT, Chuang SH, Hsu JP and others (1999) Taura syndrome in Pacific white shrimp Penaeus vannamei cultured in Taiwan. Dis Aquat Org 38: 159-161

Walker PJ, Cowley JA, Spann KM, Hodgson RAJ, Hall MR, Withychumnarnkul B (2001) Yellow head complex viruses: transmission cycles and topographical distribution in the Asia-Pacific region. In: Browdy CL, Jory DE (eds) The new wave: Proc Special Session on sustainable shrimp culture. Aquaculture 2001. World Aquaculture Society, Baton Rouge, LA, p 227-237

Walker P, Bonami J, Boonsaeng V, Chang $\mathrm{P}$ and others (2005) Family Roniviridae. In: Fauquet CM, Mayo MA, Maniloff J, Desselberger U, Ball LA (eds) Virus taxonomy. VIIIth Report of the International Committee on Taxonomy of Viruses. Elsevier, London, p 975-979

> Wang YC, Chang PS (2000) Yellow head virus infection in the giant tiger prawn Penaeus monodon cultured in Taiwan. Fish Pathol 35:1-10

White-Noble B, Lightner DV, Tang, KF, Redman R (2010) Lab challenge for selection of IMNV-resistant white shrimp. Global Aquaculture Advocate July-August, p 74-75. http://pdf.gaalliance.org/pdf/GAA-Noble-July10.pdf

$>$ Yu CI, Song YL (2000) Outbreaks of Taura syndrome in Pacific white shrimp Penaeus vannamei cultured in Taiwan. Fish Pathol 35:21-24 